\title{
Entrepreneurial Orientation and Growth in Mexican Small Business
}

\author{
Gonzalo Maldonado-Guzman ${ }^{1}$, María del Carmen Martínez-Serna ${ }^{1} \&$ Sandra Yesenia Pinzón-Castro ${ }^{1}$ \\ ${ }^{1}$ Departamento de Mercadotecnia, Universidad Autónoma de Aguascalientes, México \\ Correspondence: Gonzalo Maldonado-Guzman, Departamento de Mercadotecnia, Universidad Autónoma de \\ Aguascalientes, México. E-mail: gmaldona@correo.uaa.mx
}

Received: January 16, 2017

Accepted: February 10, 2017 Online Published: February 24, 2017

doi:10.5539/jms.v7n1p94

URL: http://doi.org/10.5539/jms.v7n1p94

\begin{abstract}
In the literature, there are various studies relating positively the entrepreneurial orientation to business performance. In such studies a great deal of variables have been introduced to measure business performance, among the variables most accepted by researchers and academics are profit and business growth. Therefore, it is possible to consider that entrepreneurial orientation plays an essential role in business growth. For that reason, this paper has the objective to analyse the existing relationship between entrepreneurial orientation and growth, by using a random sample of 318 small and medium-sixed enterprises in México. The results obtained show that proactivity, risk taking and innovativeness along with the competitive aggression and autonomy have significant and positive effects on small and medium-sized enterprises' growth.
\end{abstract}

Keywords: entrepreneurial orientation, growth, small business

\section{Introduction}

From more than two decades, Miller (1983) and Lumpkin \& Dess (1996) established the conceptual basis to carry out research on entrepreneurial orientation, they even became the pioneers in defining, on one side, that entrepreneurial orientation could be measured by five dimensions: proactivity, risks taking, innovativeness, competitive aggression and autonomy and on the other hand, the existing relationship between entrepreneurial orientation and business performance. For that reason, in the current literature there is an increased interest by researchers, academics and professionals of entrepreneurism about the importance of entrepreneurial orientation in organisations, mainly in Small and Medium Enterprises (Casillas \& Moreno, 2010).

In this sense, various authors have developed studies in which they have considered only some of the five dimensions to measure entrepreneurial orientation (Lumpkin \& Dess, 2001), other researchers have incorporated new variables external to the organisation (Wiklund, 1999; Zahra \& Garvin, 2000; Lumpkin \& Dess, 2001; Wiklund \& Shepherd, 2005). Other authors have used different internal variables (Covin \& Slevin, 1991; Borch, Huse \& Senneseth, 1999; Baum, Locke \& Smith, 2001; Wiklund \& Shepherd, 2005), whereas recently others have focused their studies on certain dimensions of business performance, such as, growth (Moreno \& Casillas, 2008; Casillas \& Moreno, 2010), which has contributed to the analysis and debate on entrepreneur orientation.

In the current literature, analysis of business growth, essentially in small and medium-sized enterprises (SMEs), it plays a critical role (Brown, Davidsson, \& Wiklund, 2001; Correa, Acosta, González, \& Medina, 2003; Littunen \& Tohmo, 2003; Delmar, Davidsson, \& Gartner, 2003; Moreno \& Casillas, 2008; Casillas \& Moreno, 2010). There are various reasons for this, among them, first, because firms that achieve greater levels of growth generally generate more jobs (Birch, Heggerty, \& Parsons, 1994; Littunen \& Tohmo, 2003). And secondly, because growth represents one of the most important dimensions of performance and it is commonly associated with other variables such as profit (Porter, 1980, 1985; Rumelt, 1991).

Additionally, the high level of growth achieved by many firms is associated to the entrepreneur behaviour of managers (Stevenson \& Jarillo, 1990; Brown et al., 2001), because business growth tends to be normally considered as consequence of proactive behaviour, risks taking and innovativeness in businesses, which as a result the adoption and implementation of an entrepreneur orientation in firms (Moreno \& Casillas, 2008). Therefore, the existing relationship between entrepreneurial orientation and business growth has been analysed and discussed in the literature from two different perspectives; first, from a conceptual point of view (Covin \& Slevin, 1991; Lumpkin \& Dess, 1996), and second from an empirical perspective (Covin \& Slevin, 1989; Lumpkin \& Dess, 2001; Wiklund \& Shepherd, 2005). 
Even with some published work in the literature relating entrepreneurial orientation and growth, still exist various questions to answer and two main limitations (Moreno \& Casillas, 2008). In the first place, research made from a multidimensional perspective of both constructs, through which the performance measurement has been done with indicators associated with both profit and growth, which are totally contradictors (Delmar et al., 2003). For this reason, it is important to analyse only entrepreneurial orientation and business growth. In the second place, diverse authors have considered that the existing relationship between entrepreneurial orientation and business performance is complex (Wiklund \& Shepherd, 2005), so it becomes better to analyse which performance variables have greater effects on entrepreneurial orientation.

Hence, the main contribution of this empirical research is the analysis of the existing relationship among entrepreneurial orientation and SMEs' growth in an emergent country, such as, México. The rest of this paper is organized in the following order, second section contains the theoretical framework, the previous empirical studies and this research' hypotheses; in third section, the research methodology is presented, the sample and the used variables; and finally, in the fourth section, the results obtained are presented, and in the fifth section, the main conclusions and discussions are depicted.

\section{Method}

In the current literature on enterprise and management sciences there are few studies that relate the constructs of entrepreneurial orientation and business growth, mainly in SMEs (Casillas \& Moreno, 2010), and only few studies published have concluded that entrepreneurial orientation has a positive and significant relationship with business growth (Covin \& Slevin, 1991; Lumpkin \& Dess, 1996; Wiklund \& Shepherd, 2005; Moreno \& Casillas, 2008). This is mainly because according to some researchers, academics and professionals of entrepreneurism, growth is an essential element that establishes in high percentage the companies' entrepreneurial behaviour (Stevenson, 1983; Covin \& Slevin, 1991; Brown et al., 2001).

Equally, Covin \& Slevin (1991) define the entrepreneurial businesses as those organisations that adopt and implement strategies that are closely related to development of innovation and growth activities, through its capabilities and less risk taking. Moreover, Stevenson (1983) and Stevenson \& Jarillo $(1986,1990)$ establish an existing relationship between entrepreneurial orientation and growth by an entrepreneurial culture that is adopted by firms. In the same way, Brown et al. (2001) conclude one dimension with the greater impact on entrepreneurial management in businesses is actually business growth.

Miller (1983) is a pioneer of business entrepreneurism and proposes three important dimensions that differentiate entrepreneurial firms: 1) proactivity, 2) risk taking, 3) innovativeness, which have been used by various researchers, academics and entrepreneurial professionals, in both, theoretical and empirical studies (Morris \& Paul, 1987; Covin \& Slevin, 1989; Naman \& Slevin, 1993; Wiklund \& Shepherd, 2005; Moreno \& Casillas, 2008; Casillas \& Moreno, 2010). Besides, Lumpkin and Dess (1996) later incorporated two more dimensions to those proposed by Miller (1983): 4) aggressive competence and 5) autonomy. Other authors considering more than these five dimensions of entrepreneurial orientation, are independent one of the other (Lumpkin \& Dess, 1996; Lumpkin, 1998; Wiklund \& Shepherd, 2005; Moreno \& Casillas, 2008).

One of the five dimensions that integrate entrepreneurial orientation, which have been widely accepted by different researchers and academics, and that offers a greater positive and significant relationship with business growth is "proactivity" (Rauch, Wiklund, Frese, \& Lumpkin, 2009), mainly because it basically refers to the advantages offered by effective and efficient use of resources, both technical and human as part of the firm, with the objective of gaining a high level growth (Lumpink \& Dess, 1996). Similarly, in the past, Miller \& Friesen (1978) concluded that proactivity should be an inherent quality of leadership by business managers.

Moreover, Venkataraman (1989) also considered that managers' proactivity represents new market opportunities for the firm, because it is commonly related to the development of new products and/or services right before main competitors and also to the strategic elimination of operations, dismissing the life cycle of products and/or services created. Likewise, March (1991) concluded from his research that proactivity is closely related to both market opportunities and to entrepreneurial behaviour that allows businesses to participate in a new niche market before main competitors. Thus, considering this research information previously established, it is possible to define the following hypothesis:

\section{H1: The higher proactivity, the higher business growth}

Rauch et al. (2000) define the existing relationship between the second dimension of entrepreneurial orientation, risk taking, apposite to proactivity, and business growth is not yet clear, because from their research carrying out a meta-analysis with 37 empirical studies concluded that entrepreneurial orientation and business performance have weak relationship. However, the skills gained by firms that commonly face risks are pushed to invest on 
what has not necessarily be the objective of improving profits but incrementing the business skills for diminishing risks, this way, improving their business performance in the long term (Casillas \& Moreno, 2010). In the same way, Lumpkin \& Dess (1996) conclude that organisation that have adopted and implemented an entrepreneurial orientation generally are considered high risks taking companies in them pursue of best results, compared to competitors. In consequence, risk taking is considered to have a positive and significant relationship with business growth. Therefore, considering this information it is possible to present the following hypothesis:

\section{H2: The higher risk taking, the higher business growth}

Innovativeness in firms is another dimension of entrepreneurial orientation that is considered by researchers, academics and professionals as a variable with a significant and positive relationship with business growth (Rauch et al., 2009; Casillas \& Moreno, 2010). Further, Moreno \& Casillas (2008) concluded that new products innovation and new processes that the businesses adopt and implement have significant and positive relationship with business growth, as the innovation strategy is one of the variables commonly considered to have strong impacts on business growth (Ansoff, 1965).

Furthermore, Schumpeter (1934) considers that innovation plays a special role in the entrepreneurial process that firms adopt, because it commonly improves in a significant manner firm's creativity. Still, Lumpkin \& Dess (1996) consider that the innovation process is characterized mainly for its market structures that are eliminated with new products and services introduction, producing in consequence firms' higher levels of growth. Therefore, several studies carried out by researchers and academics have established a positive and significant relationship between innovation and business growth (Markides, 1998; Moreno \& Casillas, 2008; Casillas \& Moreno, 2010). Then, by considering these studies it is possible to present the following hypothesis:

\section{H3: the higher business innovativeness, the higher business growth}

Lumpink \& Dess $(1996,2001)$ propose aggressive competence as an additional dimension through which it is possible to measure entrepreneurial orientation, because this variable emerges as an answer to firms' threats. Likewise, March (1991) considers that aggressive competence adopted by firms is closely related to exploitation, because entrepreneurial orientation implemented by organizations, apart from having an entrepreneurial attitude, should simultaneously maintain an aggressive competence, so it can be established on a determined market niche Therefore, this dimension, aggressive competence, of entrepreneurial orientation, can be considered as natural reaction in all companies, because it allows consolidating competitive position and business growth (Casillas \& Moreno, 2010). Thus, considering the presented information up to this point it is possible to define the following hypothesis:

\section{H4: The better aggressive competence, the better business growth}

Autonomy is the last dimension of the five used to measure entrepreneurial orientation, which has been little studied and analysed in the literature as both theoretical and empirical studies (Lumpkin \& Dess, 1996). Even when aggressive competence has been analysed in several studies (Lumpkin, 1998; Lumpkin \& Dess, 2001; Lumpkin, Martin, \& Sloat, 2005), autonomy has not been a research object in empirical studies (Rauch et al., 2009). Even though this variable constitutes a central and vital element of an entrepreneurial and innovative behaviour and it can be conceptually equivalent to an entrepreneurial activity that can generate a combination of productive resources (Burgelman, 1983). For this reason, several studies have considered that autonomy has a positive and significant relationship with business growth (Moreno \& Casillas, 2008; Rauch et al., 2009; Casillas \& Moreno, 2010). Thus, from previous information related to this dimension, it is possible to establish the following hypothesis:

\section{H5: The better autonomy, the better business growth}

In order to test the established research hypotheses, in the theoretical framework about the existing relationship between entrepreneurial orientation and growth, an empirical study was carried out using a sample of 318 SMEs operating in Aguascalientes state, México, this by considering the Mexican Enterprises Information System (SIEM from its acronym in Spanish) directory of Aguascalientes state. It contained 5,194 firms registered in June 2013. In this study, only firms having from 5 to 250 workers were considered, reducing it to 1,261 SMEs. The sample was randomly selected with a reliability level of $96 \%$ and a sample error of $\pm 4.5 \%$, resulting a total of 368 enterprises. Moreover, the survey was applied through a personal interview to 400 managers selected, from which 318 surveys were validated, obtaining a response rate of $87 \%$ and surveys were applied during August and October 2014.

To measure entrepreneurial orientation, the scale of Miller (1983) was used, with some adaptations from Covin \& Slevin (1991) and Lumpkin \& Dess (2001), who established that orientation can be measured by five 
dimensions: proactivity, risks taking, innovativeness, aggressive competence and autonomy. Each of these dimensions were measured by a scale of 6 items and all dimensions' items were measured in a 5-point Likert scale, where $1=$ total disagreement and $5=$ total agreement.

In regards to growth, it was measured with the growth on sales percentages in firms, during the last two years, because sales as an essential variable to measure business growth has been widely used in the literature by researchers and academics (Davidsson \& Wiklund, 1999; Delmar, Davidsson, \& Gartner, 2003; Moreno \& Casillas, 2008; Casillas \& Moreno, 2010). The use of this indicator results appropriate to measure growth, by having two basic considerations. First, a theoretical aspect, growth is a crucial indicator to measure rises in business activities (Davidsson \& Wiklund, 1999). Second, the empirical aspect that refers to the existing high correlations between both variables (Delmar et al., 2003).

A maximum likelihood Confirmatory Factor Analysis (CFA) was applied to evaluate reliability and validity of the entrepreneurial orientation, using the software EQS 6.2 (Bentler, 2005; Brown, 2006; Byrne, 2006). The theoretical model' reliability was evaluated through the Cronbach Alpha and the Composite Reliability Index (CRI). Moreover, following recommendations by Chou, Bentler, \& Satorra (1991) and Hu, Bentler, \& Kano (1992), about statistical data correction related to the theoretical model when normality is present, and using robust statistics that provide better adjustment to data proposed by Satorra \& Bentler (1988).

The results obtained from the CFA are shown in Table 1, demonstrating that the theoretical model about the relationship between entrepreneurial orientation and business growth have a good adjustment $\left(S-B X^{2}=414.715\right.$; $\mathrm{df}=242 ; \mathrm{p}=0.000 ; \mathrm{NFI}=0.882 ; \mathrm{NNFI}=0.928 ; \mathrm{CFI}=0.936$; RMSEA $=0.047)$. Furthermore, all items of the related factors are significant $(\mathrm{p}<0.01)$, the size of all standardized factor loads are higher than 0.60 (Bagozzi \& Yi, 1988), and the Cronbach Alpha and the CRI have a value over 0.70. Also, Extracted Variance Index (EVI) is higher than 0.50 (Fornell \& Larcker, 1981), which indicates the existence of reliability and convergent validity, justifying the reliability of the scales used (Nunally \& Bernstein, 1994; Hair et al., 1995).

Table 1. Internal consistency and convergent validity of the theoretical model

\begin{tabular}{|c|c|c|c|c|c|c|}
\hline Variable & Indicator & Factor Load & Robust Value t & Cronbach Alpha & CRI & EVI \\
\hline \multirow[t]{5}{*}{ Proactivity } & PR1 & $0.698^{* * * *}$ & $1.000^{\mathrm{a}}$ & 0.839 & 0.842 & 0.517 \\
\hline & PR2 & $0.684 * * *$ & 11.399 & & & \\
\hline & PR4 & $0.714 * * *$ & 11.678 & & & \\
\hline & PR5 & $0.739 * * *$ & 11.825 & & & \\
\hline & PR6 & $0.758 * * *$ & 12.460 & & & \\
\hline \multirow[t]{5}{*}{ Risk taking } & TR1 & $0.771 * * *$ & $1.000^{\mathrm{a}}$ & 0.867 & 0.870 & 0.574 \\
\hline & TR2 & $0.673 * * *$ & 8.431 & & & \\
\hline & TR4 & $0.788 * * *$ & 9.699 & & & \\
\hline & TR5 & $0.782 * * *$ & 10.184 & & & \\
\hline & TR6 & $0.769^{* * *}$ & 9.976 & & & \\
\hline \multirow[t]{5}{*}{ Innovativeness } & IN1 & $0.731 * * *$ & $1.000^{\mathrm{a}}$ & 0.861 & 0.864 & 0.561 \\
\hline & IN2 & $0.657 * * *$ & 13.349 & & & \\
\hline & IN3 & $0.805 * * *$ & 13.942 & & & \\
\hline & IN4 & $0.746^{* * *}$ & 11.981 & & & \\
\hline & IN5 & $0.796 * * *$ & 15.747 & & & \\
\hline Aggressive & $\mathrm{AC} 2$ & $0.735^{* * *}$ & $1.000^{\mathrm{a}}$ & 0.829 & 0.832 & 0.554 \\
\hline \multirow[t]{3}{*}{ competence } & $\mathrm{AC} 3$ & $0.729 * * *$ & 8.169 & & & \\
\hline & $\mathrm{AC} 4$ & $0.661 * * *$ & 7.706 & & & \\
\hline & AC6 & $0.842 * * *$ & 9.584 & & & \\
\hline \multirow[t]{5}{*}{ Autonomy } & AU2 & $0.833 * * *$ & $1.000^{\mathrm{a}}$ & 0.891 & 0.892 & 0.624 \\
\hline & AU3 & $0.808^{* * *}$ & 19.678 & & & \\
\hline & AU4 & $0.768 * * *$ & 18.775 & & & \\
\hline & AU5 & $0.760 * * *$ & 14.298 & & & \\
\hline & AU6 & $0.777 * * *$ & 15.972 & & & \\
\hline$S-B X^{2}(\mathrm{df}=242$ & $715 ; \mathrm{p}<0.0$ & $\mathrm{I}=0.882 ; \mathrm{NNF}$ & $928 ; \mathrm{CFI}=0.936$ & RSEA $=0.047$ & & \\
\hline
\end{tabular}

In terms of discriminant validity of the theoretical model, the evidence is provided in two forms, which are visible in Table 2. First, there is a confidence interval test defined by Anderson \& Gerbing (1988), which establishes that with a confidence interval of $95 \%$ none of the individual elements from the latent factors of the 
correlation matrix contains the value 1 . Secondly, the extracted variance text is presented, which is proposed by Fornell \& Larcker (1981), establishing that the extracted variance between each pair of constructs is lower than the corresponding EVI. In consequence, according to these results obtained, from both test, it is possible to provide sufficient evidence in relation to the discriminant validity of the theoretical model.

Table 2. Discriminant validity of the theoretical model

\begin{tabular}{llllll}
\hline Variables & Proactivity & Risk taking & Innovativeness & Aggressive Competence & Autonomy \\
\hline Proactivity & $\mathbf{0 . 5 1 7}$ & 0.117 & 0.179 & 0.069 & 0.135 \\
Risk taking & $0.243-0.443$ & $\mathbf{0 . 5 7 4}$ & 0.180 & 0.078 & 0.116 \\
Innovativeness & $0.309-0.537$ & $0.304-0.544$ & $\mathbf{0 . 5 6 1}$ & 0.068 & 0.328 \\
Aggressive Competence & $0.176-0.348$ & $0.186-0.374$ & $0.167-0.355$ & $\mathbf{0 . 5 5 4}$ & 0.077 \\
Autonomy & $0.254-0.482$ & $0.221-0.461$ & $0.425-0.721$ & $0.171-0.383$ & $\mathbf{0 . 6 2 4}$ \\
\hline
\end{tabular}

The diagonal represents the Extracted Variance Index (EVI), whereas above diagonal the part of the variance is shown (correlation). Below diagonal the estimation of factors correlation is depicted with a confidence interval of $95 \%$.

\section{Results}

In order to give an answer to the established hypothesis of the theoretical model, an structural equations model of second order, using software EQS 6.1 through a CFA second order (Bentler, 2005; Byrne, 2006; Brown, 2006), in which the nomological validity of the theoretical and measurement model were examined, by identifying that differences between both models are not significant, which allow explaining relationships observed between latent constructs (Anderson \& Gerbing, 1988; Hatcher, 1994). Table 3 shows in greater detail such results.

Table 3. Results from the structural equations model

\begin{tabular}{llll}
\hline Hypothesis & Structural relationship & Standardized Coefficient & Robust Value t \\
\hline $\begin{array}{l}\mathbf{H}_{1}: \text { The higher proactivity, the higher } \\
\text { business growth. }\end{array}$ & Proactivity $\rightarrow$ Growth & $0.206^{* * *}$ & 11.841 \\
$\begin{array}{l}\mathbf{H}_{2}: \text { The higher risk taking, the higher } \\
\text { business growth. }\end{array}$ & Risk taking $\rightarrow$ Growth & $0.220^{* * *}$ & 9.573 \\
$\begin{array}{l}\mathbf{H}_{3}: \text { The higher innovativeness, the higher } \\
\text { business growth. }\end{array}$ & Innovativeness $\rightarrow$ Growth & $0.252^{* * *}$ & 13.755 \\
$\begin{array}{l}\mathbf{H}_{4}: \text { The higher aggressive competence, } \\
\text { the higher business growth. }\end{array}$ & Aggressive Comp. $\rightarrow$ Growth & $0.191^{* * *}$ & 8.486 \\
$\begin{array}{l}\mathbf{H}_{5}: \text { The higher autonomy, the higher } \\
\text { business growth. }\end{array}$ & Autonomy $\rightarrow$ Growth & $0.307^{* * *}$ & 12.534 \\
\hline$S-B X^{2}(\mathrm{df}=236)=404.433 ; \mathrm{p}<0.000 ; \mathrm{NFI}=0.885 ; \mathrm{NNFI}=0.928 ; \mathrm{CFI}=0.938 ; \mathrm{RMSEA}=0.047$ & \\
\hline Note. $* * *=\mathrm{P}<0.01$. &
\end{tabular}

Table 3 shows the obtained results in the application of structural equations modelling. In regards to the first hypothesis $\mathbf{H}_{1}$ the results obtained $\beta=0.206 \mathrm{p}<0.01$, indicate that proactivity has positive and significant effects on SMEs growth. To test hypothesis $\mathbf{H}_{2}$ the results obtained $\beta=0.220 \mathrm{p}<0.01$ demonstrate that risk taking is positively related to SMEs growth. For the third hypothesis $\mathbf{H}_{3}$ the results obtained, $\beta=0.252 p<0.01$, indicate that innovation has a positive and significant relationship with SMEs growth. In relation to the fourth hypothesis $\mathbf{H}_{4}$ the obtained results, $\beta=0.191 \mathrm{p}<0.01$, present the existing and positive correlation between aggressive competence and SMEs growth.

To finish, about the fifth established hypothesis $\mathbf{H}_{5}$ the results obtained, $\beta=0.307 \mathrm{p}<0.01$, prove that autonomy has a positive and significant impact on SMEs growth, operating in Aguascalientes. Therefore, it is possible to conclude that a entrepreneurial orientation measured by five dimensions: proactivity, risk taking, innovativeness, aggressive competence and autonomy, apart from being good indicators to measure entrepreneurial orientation in SMEs, also have a direct and positive relationship to SMEs growth.

\section{Discussion}

From the results obtained in this empirical study it is possible to provide two main conclusions. First, the dimensions used to measure entrepreneurial orientation: proactivity, risk taking, innovativeness, aggressive competence and autonomy, generate a greater level of growth in SMEs operating in Aguascalientes state, México. 
Consequently, as organizations adopt these activities related to entrepreneurial orientation or consider entrepreneurial orientation as a organizational strategy inside their strategic planning, business' growth will increment in a significant manner, which can attract major benefits to their business financial and economical performance.

Second, the measurement of entrepreneurial orientation in SMEs is possible through five dimensions, and there is a significant and positive relationship between entrepreneurial orientation and business growth, which provides empirical evidence about the important relationship and it contributes to the theoretical and empirical debate of both constructs. Besides, it is possible to conclude that growth is a good measure of financial and economical performance in organisations, and at the same time provides evidence of its feasibility measuring business performance, specifically through sales growth. Besides, it is considered that financial and economical performance of SMEs will increase as well as organizations develop activities and actions of entrepreneurial orientation.

In this sense, there are implications, first, SMEs managers have to be more proactive, looking for the anticipation from their principal competitors to both market introduction in which they participate, and in new and improved products and services that are adapted to preferences and needs of final clients and costumers; and to design and implement activities related to entrepreneurial orientation. Additionally, managers must be conscious that they will assume several risks as being the first in offering products and services that market demands, but these risks have to be calculated that will require that SMEs collect the most possible information in terms of current and potential clients and customers' preferences and needs.

Third, managers have to include innovation activities in their daily activities, as it is not possible to think about an organization without this type of activities. Moreover, innovation has to be a priority strategy for organizations, and all departments or functional areas should work into a coordinated form, so innovation activities are continually reinforced and in this form transform actions into products and/or services demanded by actual and potential clients and customers, and into the achievement not only of greater level of growth in sales but also into better financial performance, having as final result better market position.

Fourth, high level managers in SMEs should additionally implement higher aggressive competence in market as they participate, because if a submissive or conformist position is taken by the firm against the actual position by competitors in the market, its principal competitors could take advantage of it and move the firm out from the market. Or even worst, it could take a significant percentage of the firm' clients and customers, which will take them dramatically to a decrease of sales and perhaps to quit from the market. Also, managers should create a working environment in which departments or areas could have greater autonomy in decision making, with the aim of improving firms' strategies that allow them gaining higher levels of growth and financial performance.

However, this research presents various research limitations that are important to consider for future research. First, the measurement scales both entrepreneurial orientation and growth, for which five dimensions were used to measure entrepreneurial orientation and growth, might be reinforced adding different scales, in order to corroborate the results obtained. Second, only a small part of information about entrepreneurial orientation and growth was used with qualitative variables, in data collection; for which in future research it would be useful to incorporate quantitative variables in order to corroborate the presented results.

A third limitation is about the measurement variables from both used scales, because the six items were used to measure each of these six factors of entrepreneurial orientation and only one item to measure growth, whereby in future studies it would be necessary to include another item o a greater number of items to measure both constructs. A fourth limitation is that the surveys were applied only to managers and/or owners of SMEs, which can affect the results obtained if a different population is instead used, such as, clients and suppliers. Therefore, in future research an incorporation of these populations should be considering.

The last limitation of this paper is that only SMEs with 5 to 250 workers from Aguascalientes state, México were considered, whence in future research it would be useful to include enterprises with less than five workers, which represents more than $60 \%$ of the population. To finish, it is convenient to go further on the results obtained in this research, and to analyse and to discuss deeper on issues like: What effects could exist on SMEs growth if a quantitative scale was used to measure the entrepreneurial orientation? What results can be obtained on SMEs' growth if alternative dimensions were used to measure entrepreneurial orientation? These and other questions can emerge and be answered in future research.

\section{References}

Anderson, J., \& Gerbing, D. (1988). Structural equation modelling in practice: A review and recommended two-step approach. Psychological Bulletin, 13, 411-423. 
Ansoff, H. I. (1965). Corporate strategy: An analytic approach to business policy for growth and expansion. New York, NY: McGraw-Hill.

Bagozzi, R. P., \& Yi, Y. (1988). On the evaluation of structural equation models. Journal of the Academy of Marketing Science, 16(1), 74-94. http://dx.doi.org/10.1007/BF02723327

Baum, J. R., Locke, E. A., \& Smith, K. G. (2001). A multidimensional model of venture growth. Academy of Management Journal, 44, 292-303.

Bentler, P. M. (2005). EQS 6 structural equations program manual. Encino, CA: Multivariate Software.

Birch, D., Haggerty, A., \& Parsons, W. (1994). Corporate almanac. Minnesota: Ed. Connetics Inc.

Borch, O. J., Huse, M., \& Senneseth, K. (1999). Resource configuration, competitive strategies and corporate entrepreneurship: An empirical examination of small firms. Entrepreneurship Theory and Practice, 24(1), 49-70.

Brown, T. (2006). Confirmatory factor analysis for applied research. New York, NY: The Guilford Press.

Brown, T. E., Davidsson, P., \& Wiklund, J. (2001). An operationalization of Stevenson's conceptualization of entrepreneurship as opportunity-based firm behaviour. Strategic Management Journal, 22, 953-968. http://dx.doi.org/10.1002/smj.190

Burgelman, R. A. (1983). Corporate entrepreneurship and strategic management: Insights from a process study. Management Science, 29(12), 1349-1364. http://dx.doi.org/10.1287/mnsc.29.12.1349

Byrne, B. (2006). Structural equation modelling with EQS, basic concepts, applications, and programming (2nd ed.). London: LEA Publishers.

Casillas, J. C., \& Moreno, A. M. (2010). The relationship between entrepreneurial orientation and growth: The moderating role of family involvement. Entrepreneurship \& Regional Development, 22(3-4), 265-291. http://dx.doi.org/10.1080/08985621003726135

Chou, C. P., Bentler, P. M., \& Satorra, A. (1991). Scaled test statistics and robust standard errors for nonnormal data in covariance structure analysis. British Journal of Mathematical and Statistical Psychology, 44, 347-357. http://dx.doi.org/10.1111/j.2044-8317.1991.tb00966.x

Correa, A., Acosta, M., Gonzalez, A. L., \& Medina, U. (2003). Size, age and activity sector on the growth of the small and medium firm size. Small Business Economics, 21, 289-307.

Covin, J. G., \& Slevin, D. (1989). Strategic management of small firms in hostile and benign environments. Strategic Management Journal, 10, 75-87. http://dx.doi.org/10.1002/smj.4250100107

Covin, J. G., \& Slevin, D. (1991). A conceptual model of entrepreneurship as firm behaviour. Entrepreneurship Theory and Practice, 16(1), 7-24.

Davidsson, P., \& Wiklund, J. (1999). Conceptual and empirical challenges in the study of firm growth. Paper presented at the State of the Art in Entrepreneurship Conference. Fort Lauderdale, FL: February 16-20.

Delmar, F., Davidsson, P., \& Gartner, W. B. (2003). Arriving at the high-growth firm. Journal of Business Venturing, 18, 189-217. http://dx.doi.org/10.1016/S0883-9026(02)00080-0

Fornell, C., \& Larcker, D. (1981). Evaluating structural equation models with unobservable variables and measurement error. Journal of Marketing Research, 18(1), 39-50. http://dx.doi.org/10.2307/3151312

Hair, J. F., Anderson, R. E., Tatham, R. L., \& Black, W. C. (1995). Multivariate data analysis with readings. New York, NY: Prentice-Hall.

Hatcher, L. (1994). A step by step approach to using the SAS system for factor analysis and structural equation modelling. Cary, NC: SAS Institute Inc.

Hu, L. T., Bentler, P. M., \& Kano, Y. (1992). Can test statistics in covariance structure analysis be trusted? Psychological Bulletin, 112(2), 351-362. http://dx.doi.org/10.1037/0033-2909.112.2.351

Littunen, H., \& Tohlmo, T. (2003). The high growth in new metal-based manufacturing and business service firms in Finland. Small Business Economics, 21(2), 187-200. http://dx.doi.org/10.1023/A:1025014427294

Lumpkin, G. T. (1998). Do young firms have an entrepreneurial orientation? Working Paper, University of Utah, $1-35$.

Lumpkin, G. T., \& Dess, G. G. (1996). Clarifying the entrepreneurial orientation construct and linking it to performance. Academy of Management Review, 21(1), 135-172. http://dx.doi.org/10.2307/258632 
Lumpkin, G. T., \& Dess, G. G. (2001). Linking two dimensions of entrepreneurial orientation to firm performance: The moderating role of environment industry life cycle. Journal of Business Venturing, 16, 429-451. http://dx.doi.org/10.1016/S0883-9026(00)00048-3

Lumpkin, G. T., Martin, W. L., \& Sloat, C. B. (2005). The role of entrepreneurial orientation in the performance of family firms in dynamic and hostile environment. Paper presented at the Babson College Entrepreneurship Research Conference, Glasgow, Scotland.

March, J. G. (1991). Exploration and exploitation in organizational learning. Organizational Science, 2(1), 31-42. http://dx.doi.org/10.1287/orsc.2.1.71

Markides, C. (1998). Strategic innovation in established companies. Sloan Management Review, 39(3), 31-42.

Miller, D. (1983). The correlates of entrepreneurship in three types of firms. Management Science, 29, 770-791. http://dx.doi.org/10.1287/mnsc.29.7.770

Miller, D., \& Friesen, P. (1978). Archetypes of strategy formulation. Management Science, 24, 921-933. http://dx.doi.org/10.1287/mnsc.24.9.921

Moreno A. M., \& Casillas, J. C. (2008). Entrepreneurial orientation and growth of SMEs: A causal model. Entrepreneurship Theory and Practice, 32(3), 507-528. http://dx.doi.org/10.1111/j.1540-6520.2008.00238.x

Morris, M. H., \& Paul, G. W. (1987). The relationship between entrepreneurship and marketing in established firms. Journal of Business Venturing, 2(3), 247-259. http://dx.doi.org/10.1016/0883-9026(87)90012-7

Naman, J. L., \& Slevin, D. P. (1993). Entrepreneurship and the concept of fit: A model and empirical test. Strategic Management Journal, 14(2), 137-153. http://dx.doi.org/10.1002/smj.4250140205

Nunnally, J. C., \& Bernstein, I. H. (1994). Psychometric theory (3rd ed.). New York: McGraw-Hill.

Porter, M. (1980). Competitive strategy. New York, NY: Free Press.

Porter, M. (1985). Competitive advantage. New York, NY: Free Press.

Rauch, A., Wiklund, J., Frese, M., \& Lumpkin, G. T. (2009). Entrepreneurial orientation and business performance: An assessment of past research and suggestions for the future. Entrepreneurship Theory and Practice, 33(3), 761-781. http://dx.doi.org/10.1111/j.1540-6520.2009.00308.x

Rumelt, R. P. (1991). How much does industry matter? Strategic Management Journal, 12(3), 167-185. http://dx.doi.org/10.1002/smj.4250120302

Satorra, A., \& Bentler, P. M. (1988). Scaling corrections for chi square statistics in covariance structure analysis. American Statistics Association 1988 Proceedings of the Business and Economic Sections, 208-313.

Schumpeter, J. (1934). Capitalism, socialism and democracy. New York, NY: Harper and Row.

Stevenson, H. H. (1983). A perspective on entrepreneurship. Harvard Business School, Working Paper 9, $384-431$.

Stevenson, H. H., \& Jarillo, J. C. (1986). Preserving entrepreneurship as companies' growth. Journal of Business Strategy, 6, 10-23.

Stevenson, H. H., \& Jarillo, J. C. (1990). A paradigm of entrepreneurship: Entrepreneurial management. Strategic Management Journal, 11, 17-27.

Venkataraman, N. (1989). Strategic orientation of business enterprises: The construct, dimensionality and measurement. Management Science, 35, 942-962.

Wiklund, J. (1999). The sustainability of the entrepreneurial orientation: Performance relationship. Entrepreneurship Theory and Practice, 24(1), 37-48.

Wiklund, J., \& Shepherd, D. (2005). Entrepreneurial orientation and small business performance: A configurational approach. Journal of Business Venturing, 20(1), 71-91. http://dx.doi.org/10.1016/j.jbusvent.2004.01.001

Zahra, S., \& Garvin, D. (2000). International corporate entrepreneurship and firm performance: The moderating effects of international environment hostility. Entrepreneurship Theory and Practice, 15, 469-492. 


\section{Copyrights}

Copyright for this article is retained by the author(s), with first publication rights granted to the journal.

This is an open-access article distributed under the terms and conditions of the Creative Commons Attribution license (http://creativecommons.org/licenses/by/4.0/). 